\title{
STUDY OF ORAL VERSUS INTRAVENOUS IRON THERAPY IN POSTPARTUM ANAEMIC WOMEN
}

\author{
Sharmila Pradhan'1, Ojaswini Patel2, Malayiltharayil Deepti Raju³, Pragyan Dash ${ }^{4}$ \\ ${ }^{1}$ Assistant Professor, Department of Obstetrics and Gynaecology, VIMSAR, Burla. \\ ${ }^{2}$ Associate Professor, Department of Obstetrics and Gynaecology, VIMSAR, Burla. \\ $3 J u n i o r$ Resident, Department of Obstetrics and Gynaecology, VIMSAR, Burla. \\ 4 Junior Resident, Department of Obstetrics and Gynaecology, VIMSAR, Burla.
}

\section{ABSTRACT}

\section{BACKGROUND}

Anaemia is a serious nutrition problem affecting millions in developing countries and remains a major challenge for human health and social and economic development. Iron deficiency is thought to be the most common cause of anaemia globally.

\section{MATERIALS AND METHODS}

It was a prospective randomised controlled trial, single centric study involving women with postpartum IDA. Improvements of those who were treated with injectable iron were compared with those who were treated with oral iron.

\section{RESULTS}

The demographic variables like age, BMI, habitat, dietary habits, parity, antenatal presence of anaemia, modes of delivery and type of risk factors were comparable. In oral iron therapy group, mean Hb on Day 0 was $8.008 \pm 0.5435 \mathrm{gm} / \mathrm{dL}$. On $2^{\text {nd }}$ week mean $\mathrm{Hb}$ rises to $8.924 \pm 0.7660 \mathrm{gm} / \mathrm{dL}$ and on $6^{\text {th }}$ week mean $\mathrm{Hb}$ rises to $9.889 \pm 0.9467 \mathrm{gm} / \mathrm{dL}$. In injectable iron therapy group mean $\mathrm{Hb}$ on Day 0 was $7.822 \pm 0.5422 \mathrm{gm} / \mathrm{dL}$, in the $2^{\text {nd }}$ week mean rise in $\mathrm{Hb}$ was $10.362 \pm 0.9354 \mathrm{gm} / \mathrm{dL}$ and in $6^{\text {th }}$ week Hb rise was $12.858 \pm 0.6616 \mathrm{gm} / \mathrm{dL}$.

\section{CONCLUSION}

Intravenous iron therapy administration increases the haemoglobin level and iron store more rapidly than oral iron intake in women with iron deficiency anaemia in the postnatal period. It can be used as safe and effective alternative to blood transfusion and oral iron therapy in the treatment of iron deficiency anaemia in the postpartum period. If cost is not a limiting factor, limited dosage schedule of iron sucrose as prescribed in the study is a safe and effective alternative to daily oral iron taken in treatment of postpartum anaemia. Multiple child birth, poor socioeconomic status, dietary habits, type of habitat and education status of mother also contributed to the incidence of postpartum anaemia.

\section{KEYWORDS}

Iron Deficiency Anaemia, Serum Iron, Serum Ferritin, Postpartum.

HOW TO CITE THIS ARTICLE: Pradhan S, Patel O, Raju MD, et al. A study of oral versus intravenous iron therapy in postpartum anaemic women. J. Evolution Med. Dent. Sci. 2017;6(54):4101-4106, DOI: 10.14260/Jemds/2017/886

\section{BACKGROUND}

Anaemia is a serious nutrition problem affecting millions in developing countries and remains a major challenge for human health and social and economic development. Anaemia is a condition in which the number of red blood cells or their oxygen-carrying capacity is insufficient to meet physiologic needs which vary by age, sex, altitude, smoking and pregnancy status. Anaemia in pregnancy is defined by WHO as Haemoglobin below $11 \mathrm{gm} / \mathrm{dL}$. ${ }^{[1]}$ It is recommended that postpartum anaemia should be defined by haemoglobin $<11 \mathrm{~g} / \mathrm{dL}$ at 1 week postpartum and $<12 \mathrm{~g} / \mathrm{dL}$ at 8 weeks postpartum. The major causes of postpartum anaemia are prepartum anaemia combined with acute bleeding anaemia due to blood losses at delivery.[2] In consecutive European women, the prevalence of anaemia $48 \mathrm{hrs}$. after delivery is

Financial or Other, Competing Interest: None.

Submission 30-05-2017, Peer Review 23-06-2017,

Acceptance 29-06-2017, Published 06-07-2017.

Corresponding Author:

Dr. Ojaswini Patel,

Behind Patel Nursing Home,

Kirba, Burla

Sambalpur-768018, Odisha.

E-mail:drojaswinipatel@yahoo.co.in

DOI: $10.14260 /$ jemds $/ 2017 / 886$

\section{(c) $($ ) $\odot$}

approximately 50\%. In developing countries, the prevalence of postpartum anaemia is in the range of $50-80 \% .^{[3]}$ There are various possible forms of treatment for post-partum iron deficiency anaemia.

Iron can be given orally by intramuscular route or intravenous method. Oral iron therapy can be used for mild anaemia, while intravenous and intramuscular iron therapy can be given in patients with severe anaemia.[1] There are cases where parenteral iron is preferable over oral iron. These are cases where oral iron is not tolerated, where the haemoglobin needs to be increased quickly, where there is an underlying inflammatory condition or renal patients, the benefits of parenteral iron far outweigh the risks.[4]

We are in search of an iron preparation, which can increase the haemoglobin in shorter interval with fewer side effects. Here, we have chosen iron sucrose to see the results mainly in respect of time taken for the increase in haemoglobin and serum ferritin.
Aims and Objectives
The Primary aim is to evaluate the efficacy of intravenous (newer molecule-iron sucrose) iron compared to oral iron therapy in the management of Iron Deficiency Anaemia (IDA) in postpartum anaemia. The Secondary aim is to analyse the prevalence of postpartum anaemia in rural setup, the effect of 
use of intravenous iron sucrose complex in improvement of haemoglobin levels and serum ferritin and to study the adverse effect of these therapies in both groups.

\section{MATERIALS AND METHODS}

It was a prospective randomised controlled trial; single centric study was conducted in the Dept. of Obstetrics and Gynaecology, VSSIMSAR, Burla for the duration of 2 years, November 2014 to November 2016. Ethical Committee Clearance was obtained before commencing the study. All patients were enrolled after duly signed informed consent. After careful history taking, clinical examination and minimal investigations, other causes of anaemia were ruled out. The initial iron status of the woman was assessed by the clinical and laboratory examinations (complete blood picture and serum ferritin levels). A total of 100 postpartum women who had developed postpartum IDA (having Hb levels between 7 $9 \mathrm{gm} / \mathrm{dL}$ and serum ferritin level less than $15 \mu \mathrm{g} / \mathrm{mL}$ at 24 48 hours post-delivery) were included in the study based on inclusion and exclusion criteria. All 100 women were allotted serial number of $1-100$, those having odd numbers were recruited in Group A and those having even numbers were recruited in Group B, each group having 50 members.

\section{Group A (Injectable Iron Therapy Group)}

50 patients included in this group received divided dose of intravenous ferrous sucrose calculated according to body weight and $\mathrm{Hb}$ deficit.

\section{Dose Calculated}

In postpartum anaemia $=2.4 \times \mathrm{W} \times \mathrm{D}+500$

$\mathrm{W}=$ Weight of patient in $\mathrm{kg}$

$\mathrm{D}=$ Target $\mathrm{Hb}-$ Actual $\mathrm{Hb}$

Target haemoglobin in postpartum anaemia $=12 \mathrm{gm} / \mathrm{dL}$.

$500 \mathrm{mg}$ for body iron stores in lactation.

2.4 - from blood volume which is $7 \%$ of body weight and iron content of $\mathrm{Hb}$, which is $0.34 \% .0 .07 \times 0.0034 \times 100=2.4$ (Conversion from $\mathrm{g} / \mathrm{dL}$ to $\mathrm{mg}$ ).

Iron sucrose is given by IV injection according to iron deficit calculated and rounded up to nearest multiple of 100 for each individual; $200 \mathrm{mg}$ of elemental iron diluted in 200 $\mathrm{mL}$ normal $0.9 \%$ saline was maximum dose given as slow IV over $30 \mathrm{mts}$ in the study and was repeated on alternate days when necessary. Treatment was stopped after administration of the calculated dose. Patients during the treatment were monitored for any signs and symptoms of reactions.

\section{Group B (Oral Ferrous Sulphate Group)}

50 patients included in this group were advised to take 200 $\mathrm{mg}$ of ferrous sulphate twice daily for 6 weeks. Women were advised to document treatment compliance and symptoms.

Blood samples of patients were taken at the day of recruitment into the study (Day 0) and the rest of the samples were taken in 2 weeks and 6 weeks after the start of the treatment to detect any difference in the speed of restoration of Haemoglobin and serum ferritin. Improvement of mean haemoglobin, mean serum ferritin level, adverse reactions tolerability of Group A (injectable iron) compared with Group B (oral ferrous sulphate iron).

Statistical analysis (mean, standard deviation, unpaired ttest) was done by SPSS Inc. USA. Confidence interval (95\%) of various proportions was calculated. $\mathrm{P}<0.05$ was taken as significant.

\section{Inclusion Criteria}

The study population consisted of women with postpartum IDA (defined as $\mathrm{Hb}$ of between 7 to $9 \mathrm{gm} / \mathrm{dL}$ and serum ferritin of $<15$ micrograms/L at 24 - 48 hours post-delivery).

\section{Exclusion Criteria}

The women with previous iron therapy during pregnancy, intolerance to iron derivatives, peripartum blood transfusion or a history of asthma, thromboembolism, seizures, alcohol or drug abuse. Women with signs of infection or evidence of renal or hepatic dysfunction patients with sickle cell anaemia, thalassemia, megaloblastic anaemia and other types of anaemia except iron deficiency anaemia.

\section{RESULTS}

\begin{tabular}{|c|c|c|c|}
\hline Parameters & Oral Iron & Iron Sucrose & $\mathbf{P}$ \\
\hline Mean age (in years) & $25.34 \pm 3.836$ & $23.7 \pm 3.775$ & 0.832 \\
\hline BMI & $21.2774 \pm 2.328$ & $21.1632 \pm 1.471$ & 0.640 \\
\hline Habitat (rural/urban) & $31 / 19(62 \% / 39 \%)$ & $32 / 18(64 \% / 36 \%)$ & 0.063 \\
\hline Dietary habits (non-veg/veg) & $37 / 13(74 \% / 26 \%)$ & $38 / 12(76 \% / 24 \%$ & 0.879 \\
\hline Parity (primi/multi) & $23 / 27(46 \% / 54 \%)$ & $18 / 32(36 \% / 64 \%)$ & 1.033 \\
\hline Antenatal anaemia & $31(62 \%)$ & $34(68 \%)$ & 0.523 \\
\hline Delivery (LSCS/VD) & $28 / 22(56 \% / 44 \%)$ & $38 / 12(76 \% / 24 \%)$ & 0.03 \\
\hline \multicolumn{4}{|l|}{ Type of risk factor } \\
\hline $\mathrm{PPH}$ & $16(32 \%)$ & $13(26 \%)$ & 0.5777 \\
\hline Hypertensive disorder & $19(38 \%)$ & $17(34 \%)$ & 0.7388 \\
\hline Placenta previa & $4(8 \%)$ & $7(14 \%)$ & 0.365 \\
\hline Multiple pregnancy & $4(8 \%)$ & $5(10 \%)$ & 0.738 \\
\hline Exclusive breast feeding/non-exclusive & $17 / 33(34 \% / 66 \%)$ & $16 / 34(32 \% / 68 \%)$ & 0.831 \\
\hline Baseline $\mathrm{Hb}(\mathrm{gm} / \mathrm{dL})$ & $8.008 \pm 0.543$ & $7.822 \pm 0.542$ & 0.7 \\
\hline Baseline ferritin $(\mu \mathrm{g} / \mathrm{dL})$ & $11.5796 \pm 0.680$ & $11.9206 \pm 0.936$ & 0.05 \\
\hline
\end{tabular}


The demographic variables like age, BMI, habitat, dietary habits, parity, antenatal presence of anaemia, modes of delivery and type of risk factors were comparable ( $p>0.05)$.

Delivery by caesarean section, postpartum haemorrhage, hypertensive disorders of pregnancy, placenta previa and multiple gestations were among the leading risk factors.

Baseline $\mathrm{Hb}$ in oral iron therapy group was $8.008 \pm 0.543$ $\mathrm{gm} / \mathrm{dL}$ and serum ferritin was $11.5796 \pm 0.680 \mu \mathrm{g} / \mathrm{L}$.

Baseline $\mathrm{Hb}$ in injectable iron therapy group was $7.822 \pm$ $0.542 \mathrm{gm} / \mathrm{dL}$ and serum ferritin was $11.9206 \pm 0.936 \mu \mathrm{g} / \mathrm{L}$.

\section{Distribution of Patients according to Habitat}

Among the patients with postpartum anaemia in my study group, $63 \%$ belonged to rural area and rest $37 \%$ belonged to urban area.[5]

\begin{tabular}{|c|c|c|c|}
\hline Parity & $\begin{array}{c}\text { Oral iron } \\
\text { Therapy Group }\end{array}$ & $\begin{array}{c}\text { Injectable Iron } \\
\text { Therapy Group }\end{array}$ & Total \\
\hline Primiparous & $23(46 \%)$ & $18(36 \%)$ & 41 \\
\hline Multiparous & $27(54 \%)$ & $32(64 \%)$ & 59 \\
\hline \multicolumn{2}{|r|}{ Table 2. Distribution of Patients according to Parity } \\
\hline
\end{tabular}

Above table shows most of the patients were multigravida $59 \%$ and rest $41 \%$ were primigravida. In oral group, $46 \%$ were primiparous and 54\% were multiparous. In injectable group, $36 \%$ were primiparous and $64 \%$ were multiparous.[6]

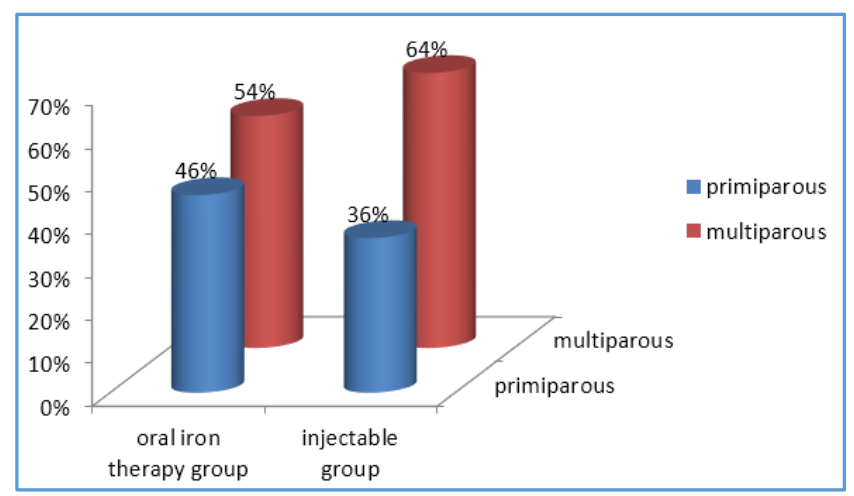

Graph 1. Distribution of Patients according to Parity

Age Wise Distribution of Postpartum Anaemic Patients based on Oral and Intravenous Iron Therapy Group In Oral Iron Therapy group 8\% patients were under 20 years of age, $38 \%$ were between 20 - 24 years, $40 \%$ patients were between 25 - 29 years of age and 7 were above 30 .

In Injectable group of iron therapy 18\% were below 20 years of age, $44 \%$ were between $20-24,30 \%$ were between 25 - 29 and $8 \%$ were above 30 years of age. ${ }^{[7]}$
Education Status Distribution of Post-Partum Anaemic Patients based on Oral and Intravenous Iron Therapy Group

In Oral Iron Therapy group 34\% were illiterate, $22 \%$ had primary education, $28 \%$ had secondary education and $16 \%$ were graduated. In Intravenous Iron Therapy group 22\% were illiterate, $38 \%$ had primary education, $30 \%$ had secondary education and $10 \%$ were graduates. ${ }^{[8]}$

\begin{tabular}{|c|c|c|}
\hline Socioeconomic Status & No. of Patients & Percentage \\
\hline 1 & 39 & 39 \\
\hline 2 & 37 & 37 \\
\hline 3 & 24 & 24 \\
\hline \multicolumn{2}{|c|}{ Table 3. Distribution of Patients } \\
according to Socio-Economic Status \\
\hline
\end{tabular}

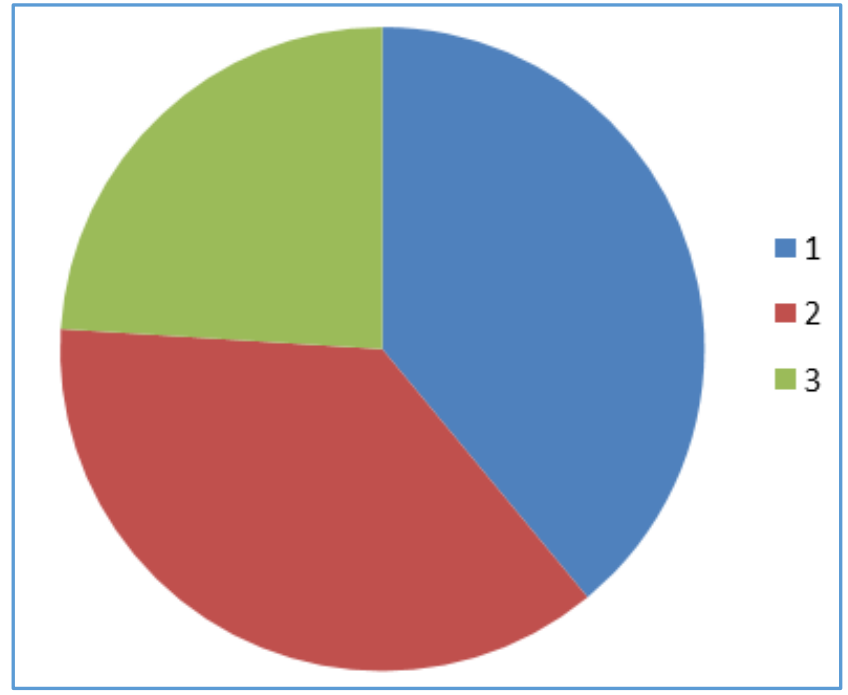

Graph 2: Distribution of Patients according to Socio-Economic Status

1- < Rs. $10000 /$ month, 2- Rs. 10000 - 20000/month, 3- > Rs. $20000 /$ month.

Most of the patients belonged to group 1 (39\%), group 2 (37\%) and $24 \%$ patients belonged to group 3 .

\begin{tabular}{|c|c|c|c|}
\hline $\begin{array}{l}\text { Socioeconomic } \\
\text { Status (Group) }\end{array}$ & $\begin{array}{c}\text { Oral Iron } \\
\text { Therapy Group }\end{array}$ & $\begin{array}{c}\text { Intravenous Iron } \\
\text { Therapy Group }\end{array}$ & Total \\
\hline 1 & $19(38 \%)$ & $20(40 \%)$ & 39 \\
\hline 2 & $18(36 \%)$ & $19(38 \%$ & 37 \\
\hline 3 & $13((26 \%)$ & $11(22 \%)$ & 24 \\
\hline & 50 & 50 & 100 \\
\hline
\end{tabular}

Table 4. Socioeconomic Distribution of Postpartum Anaemic Patients based on Oral and Intravenous Iron Therapy Group

In the oral group 38\% were in group 1, 36\% in group 2 and $26 \%$ in group 3 . In the intravenous iron therapy group $40 \%$ were in group 1, 38\% in group 2 and $22 \%$ in group 3.[9]

\begin{tabular}{|c|c|c|c|c|c|c|}
\hline \multirow{2}{*}{ Hb gm\% } & \multicolumn{3}{|c|}{ Oral Iron } & \multicolumn{3}{c|}{ Injectable Iron } \\
\cline { 2 - 7 } & Day 0 & 2 Weeks & $\mathbf{6}$ Weeks & Day 0 & 2 Weeks & $\mathbf{6}$ Weeks \\
\hline $7-8$ & $20(40 \%)$ & $4(8 \%)$ & 0 & $28(56 \%)$ & 00 & 00 \\
\hline $8-9$ & $30(60 \%)$ & $18((36 \%)$ & $8(16 \%)$ & $22(44 \%)$ & $2(4 \%)$ & 00 \\
\hline $9-10$ & 00 & $22(44 \%)$ & $17(34 \%)$ & 00 & $16(32 \%)$ & 00 \\
\hline $10-11$ & 00 & $6(12 \%)$ & $11(22 \%)$ & 00 & $14(28 \%)$ & 00 \\
\hline $11-12$ & 00 & 00 & $13(26 \%)$ & 00 & $16(32 \%)$ & $5(10 \%)$ \\
\hline$\geq 12$ & 00 & 00 & $1(2 \%)$ & 00 & $2(4 \%)$ & $45(90 \%)$ \\
\hline Total & $\mathbf{5 0}$ & $\mathbf{5 0}$ & $\mathbf{5 0}$ & $\mathbf{5 0}$ & $\mathbf{5 0}$ & $\mathbf{5 0}$ \\
\hline
\end{tabular}


In the Oral Iron Therapy group, $40 \%$ patients were having $\mathrm{Hb}$ between $7-8 \mathrm{gm} / \mathrm{dL}$ and $60 \%$ patients were having between $8-9 \mathrm{gm} / \mathrm{dL}$.

After treatment on oral iron therapy in 2 weeks nearly $44 \%$ patients showed increase in $\mathrm{Hb}$ to $9-10 \mathrm{gm} / \mathrm{dL}, 12 \%$ patients between $10-11 \mathrm{gm} / \mathrm{dL}, 36 \%$ patients between $8-9$ $\mathrm{gm} / \mathrm{dL}$, while $4 \%$ patients still had Hb between 7 - $8 \mathrm{gm} / \mathrm{dL}$.

In the $6^{\text {th }}$ week, only $2 \%$ patients showed rise in $\mathrm{Hb}$ to $\geq$ $12 \mathrm{gm} / \mathrm{dL} ; 26 \%$ patients had Hb between $11-12 \mathrm{gm} / \mathrm{dL}, 22 \%$ had risen in $\mathrm{Hb}$ between $10-11 \mathrm{gm} / \mathrm{dL}$ and $34 \%$ patients had Hb between $9-10 \mathrm{gm} / \mathrm{dL}$, but $16 \%$ patients were still having $\mathrm{Hb}$ between $8-9 \mathrm{gm} / \mathrm{dL}$.

\section{In Injectable Iron Therapy Group}

On Day 0, 44\% patients had $\mathrm{Hb}$ between $8-9 \mathrm{gm} / \mathrm{dL}$ and $56 \%$ patients had $\mathrm{Hb}$ between 7 - $8 \mathrm{gm} / \mathrm{dL}$.

In the $2^{\text {nd }}$ week $4 \%$ patients showed rise in $\mathrm{Hb}$ to $\geq 12$ $\mathrm{gm} / \mathrm{dL}, 32 \%$ patients had rise in $\mathrm{Hb}$ to $11-12 \mathrm{gm} / \mathrm{dL}, 28 \%$ patients had risen between $10-11 \mathrm{gm} / \mathrm{dL}, 32 \%$ patients had rise in $\mathrm{Hb}$ between $9-10 \mathrm{gm} / \mathrm{dL}$ and $4 \%$ patients remained between $8-9 \mathrm{gm} / \mathrm{dL}$.

In the $6^{\text {th }}$ week, $90 \%$ patients showed rise in $\mathrm{Hb} \geq 12$ gm/dL and $10 \%$ patients had Hb between $11-12 \mathrm{gm} / \mathrm{dL}$.

\begin{tabular}{|c|c|c|c|c|c|c|}
\hline \multirow{2}{*}{$\begin{array}{l}\text { Serum } \\
\text { Ferritin } \\
(\mu \mathrm{G} / \mathrm{L})\end{array}$} & \multicolumn{3}{|c|}{ Oral Iron } & \multicolumn{3}{|c|}{ Injectable Iron } \\
\hline & $\begin{array}{c}\text { Day } \\
0\end{array}$ & $\begin{array}{c}2 \\
\text { Weeks }\end{array}$ & $\begin{array}{c}6 \\
\text { Weeks }\end{array}$ & $\begin{array}{c}\text { Day } \\
0\end{array}$ & $\begin{array}{c}2 \\
\text { Weeks }\end{array}$ & \begin{tabular}{|c|}
6 \\
Weeks
\end{tabular} \\
\hline$<15$ & 50 & $46(92 \%)$ & $28(56 \%)$ & 50 & 00 & 00 \\
\hline $15-50$ & 00 & $4(8 \%)$ & \begin{tabular}{|l|}
$22(44 \%)$ \\
\end{tabular} & 00 & $42(84 \%)$ & $11(22 \%)$ \\
\hline \multirow{2}{*}{$>50$} & 00 & 00 & 00 & 00 & $8(16 \%)$ & $39(78 \%)$ \\
\hline & 50 & 50 & 50 & 50 & 50 & 50 \\
\hline \multicolumn{7}{|c|}{$\begin{array}{c}\text { Table 6. Comparison between Two Modalities of Iron } \\
\text { Therapy in relation to Improvement in Serum Ferritin } \\
\text { Level }\end{array}$} \\
\hline
\end{tabular}

\section{Oral Iron Therapy Group}

After treatment in $2^{\text {nd }}$ week, $46(92 \%)$ patients had serum ferritin below $15 \mu \mathrm{g} / \mathrm{L}$ and 4 (8\%) patients had serum ferritin between $15-50 \mu \mathrm{g} / \mathrm{L}$. In the $6^{\text {th }}$ week, $22(44 \%)$ patients had serum ferritin between $15-50 \mu \mathrm{g} / \mathrm{L}$ and 28 (56\%) still had serum ferritin below $15 \mu \mathrm{g} / \mathrm{L}$.

\section{Injectable Iron Therapy Group}

In the $2^{\text {nd }}$ week nearly $16 \%$ patients showed rise in serum ferritin $>50 \mu \mathrm{g} / \mathrm{L}$ and $84 \%$ patients had serum ferritin between $15-50 \mu \mathrm{g} / \mathrm{L}$. In the $6^{\text {th }}$ week, $78 \%$ patients had rise in serum ferritin $>50 \mu \mathrm{g} / \mathrm{L}$ and $22 \%$ patients had serum ferritin between $15-50 \mu \mathrm{g} / \mathrm{L}$.

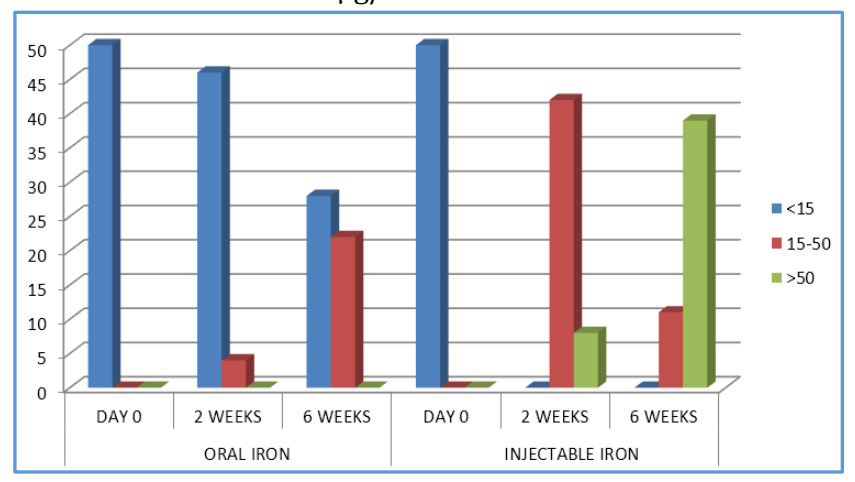

Graph 3. Comparison between Two Modalities of Iron Therapy in relation to Improvement in Serum Ferritin Level

\begin{tabular}{|c|c|c|c|c|c|}
\hline $\begin{array}{c}\text { Haemo- } \\
\text { globin }\end{array}$ & $\begin{array}{c}\text { Mean } \\
\text { Hb in } \\
\text { Oral } \\
\text { Iron } \\
\text { Group }\end{array}$ & $\begin{array}{c}\text { Standard } \\
\text { Deviation }\end{array}$ & $\begin{array}{c}\text { Mean Hb } \\
\text { in Inject- } \\
\text { able } \\
\text { Group }\end{array}$ & $\begin{array}{c}\text { Standard } \\
\text { Deviation }\end{array}$ & P value \\
\hline Day 0 & 8.008 & 0.5435 & 7.822 & 0.5422 & 0.7 \\
\hline 2 weeks & 8.924 & 0.7660 & 10.362 & 0.9354 & 0.001 \\
\hline 6 weeks & 9.889 & 0.9467 & 12.858 & 0.6616 & $0.0001 *$ \\
\hline
\end{tabular}

Table 7. Comparison of Mean and Standard Deviation in Haemoglobin Level in both Treatment Modalities

In oral iron therapy group, mean $\mathrm{Hb}$ on Day 0 was $8.008 \pm$ $0.5435 \mathrm{gm} / \mathrm{dL}$. On $2^{\text {nd }}$ week, rise in mean $\mathrm{Hb}$ was $8.924 \pm$ $0.7660 \mathrm{gm} / \mathrm{dL}$ and on $6^{\text {th }}$ week mean rise in $\mathrm{Hb}$ was $9.889 \pm$ $0.9467 \mathrm{gm} / \mathrm{dL}$.

In injectable iron therapy group mean $\mathrm{Hb}$ on Day 0 was $7.822 \pm 0.5422 \mathrm{gm} / \mathrm{dL}$, in the $2^{\text {nd }}$ week mean rise in $\mathrm{Hb}$ was $10.362 \pm 0.9354 \mathrm{gm} / \mathrm{dL}$ and in $6^{\text {th }}$ week $\mathrm{Hb}$ rise was $12.858 \pm$ $0.6616 \mathrm{gm} / \mathrm{dL}$. These values were found to be statistically significant with $p$ value of $<0.05$ and $<0.0001$ for $2^{\text {nd }}$ and $6^{\text {th }}$ week respectively.

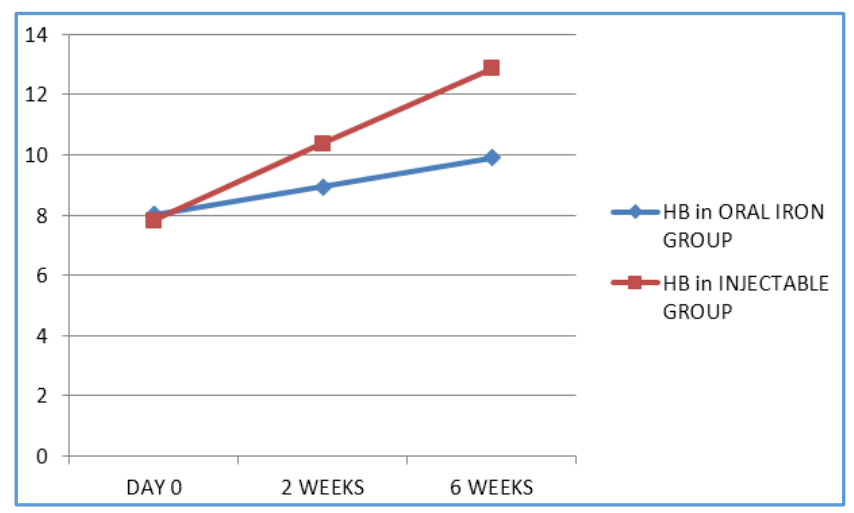

Graph 4. Comparison of Mean and Standard Deviation in Haemoglobin Level in both Treatment Modalities

\begin{tabular}{|c|c|c|c|c|c|}
\hline $\begin{array}{c}\text { Serum } \\
\text { Ferritin }\end{array}$ & $\begin{array}{c}\text { Mean } \\
\text { Serum } \\
\text { Ferritin in } \\
\text { Oral Iron } \\
\text { Group }\end{array}$ & $\begin{array}{c}\text { Mean } \\
\text { Standard } \\
\text { Deviation } \\
\text { Ferritin } \\
\text { in } \\
\text { Injectable } \\
\text { Group }\end{array}$ & $\begin{array}{c}\text { Standard } \\
\text { Deviation }\end{array}$ & P value \\
\hline Day 0 & 11.579 & 0.6809 & 11.920 & 0.9369 & 0.05 \\
\hline 2 weeks & 13.057 & 1.033 & 48.907 & 1.542 & 0.001 \\
\hline 6 weeks & 15.063 & 1.089 & 53.885 & 5.111 & $\begin{array}{c}0.0000 \\
1 *\end{array}$ \\
\hline \multicolumn{5}{|c|}{ Table 8. Mean and Standard Deviation of } \\
Serum Ferritin in both Treatment Modalities \\
\hline
\end{tabular}

In oral group of iron therapy, mean serum ferritin was $11.579 \pm 0.6809 \mu \mathrm{g} / \mathrm{L}$ on Day 0 , which showed rise in mean serum ferritin to $13.057 \pm 1.033 \mu \mathrm{g} / \mathrm{L}$ in $2^{\text {nd }}$ week and in $6^{\text {th }}$ week it had increased to $15.063 \pm 1.089 \mu \mathrm{g} / \mathrm{L}$.

In the injectable iron group on Day 0 mean serum ferritin was $11.920 \pm 0.9369 \mu \mathrm{g} / \mathrm{L}$, in $2^{\text {nd }}$ week mean serum ferritin was $48.907 \pm 1.542 \mu \mathrm{g} / \mathrm{L}$ and mean serum ferritin was 53.885 $\pm 5.111 \mu \mathrm{g} / \mathrm{L}$ in $6^{\text {th }}$ week.[10] 
Above values were found to be statistically significant with $\mathrm{p}$ value $<0.05$ and $<0.00001$ in $2^{\text {nd }}$ and $6^{\text {th }}$ week respectively.[11]

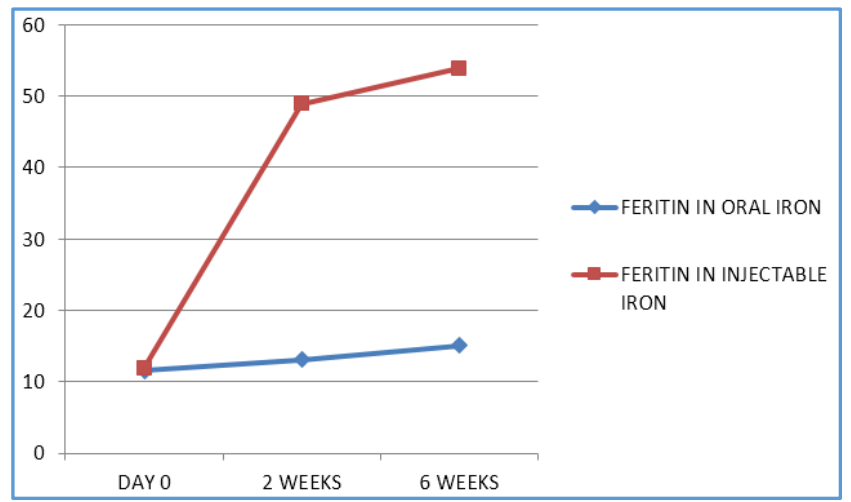

Graph 5. Mean and Standard Deviation of Serum Ferritin in both Treatment Modalities

\begin{tabular}{|c|c|c|c|c|c|}
\hline $\begin{array}{c}\text { Adverse } \\
\text { Effects of } \\
\text { Oral Iron }\end{array}$ & $\begin{array}{c}\text { No. of } \\
\text { Patients }\end{array}$ & $\%$ & $\begin{array}{c}\text { Adverse } \\
\text { Effects of } \\
\text { Injectable } \\
\text { Iron }\end{array}$ & $\begin{array}{c}\text { No. of } \\
\text { Patients }\end{array}$ & $\%$ \\
\hline Heartburn & 02 & $4 \%$ & Anaphylaxis & 00 & \\
\hline Constipation & 04 & $8 \%$ & Hypotension & 00 & \\
\hline Vomiting & 00 & & Headache & 00 & \\
\hline Nausea & 03 & $6 \%$ & Nausea & 00 & \\
\hline Metallic taste & 03 & $6 \%$ & Urticaria & 00 & \\
\hline $\begin{array}{c}\text { Epigastric } \\
\text { pain }\end{array}$ & 00 & & Flushing & 03 & $6 \%$ \\
\hline Diarrhoea & 01 & $2 \%$ & Metallic taste & 01 & $2 \%$ \\
\hline Total & 13 & $\mathbf{2 6 \%}$ & Total & $\mathbf{0 4}$ & $\mathbf{8 \%}$ \\
\hline \multicolumn{7}{|c|}{ Table 9. Adverse Reactions to Intravenous } \\
Iron Sucrose and Oral Iron Therapy \\
\hline \multicolumn{7}{|c|}{}
\end{tabular}

In oral iron therapy group out of total 50 patients, 13 $(26 \%)$ patients had adverse reaction while taking oral iron; 2 (4\%) patients had heart burn, $4(8 \%)$ of them had constipation, $3(6 \%)$ had nausea, $3(6 \%)$ had metallic taste and 1 had diarrhoea.[12]

In intravenous iron therapy group, out of 50 patients only $4(8 \%)$ patients reported to have adverse reactions. $3(6 \%)$ reported to have flushing and $1(2 \%)$ had metallic taste.[13]

\section{DISCUSSION}

Treatment of postpartum anaemia is very important to build up iron reserves in the puerperal, to have a better quality of life and to minimise incidence of anaemia in next pregnancy. So the following study was done to see whether giving iron by intravenous route in the form of iron sucrose to women with postpartum anaemia results in higher haemoglobin concentrations and improved iron stores than using standard treatment with oral iron.[13][14]

In this study [Table No. 1] during the initially screening and recruitment of postpartum patients in the labour room and ward based on inclusion and exclusion criteria, 310 out of 440 mothers were found to be anaemic (70.45\%). Among the anaemic cases $153(34.7 \%)$ were having mild anaemia, $110(25 \%)$ were having moderate anaemia and $47(10.68 \%)$ were having severe anaemia. Three of the patients did not give consent for participating in the study and other 6 patients refused for followup. Thus, 100 patients were selected randomly based on Haemoglobin 7 - $9 \mathrm{gm} / \mathrm{dL}$ and serum ferritin $<15 \mu \mathrm{g} / \mathrm{L} \cdot{ }^{[15][16]}$

In this study, demographic variables were compared in the two groups of oral and intravenous iron therapy in terms of age, body mass index, habitat, parity, dietary habits, presence of antenatal anaemia, modes of delivery and type of risk factors $(p>0.05)$. Delivery by caesarean, presence of antenatal anaemia and hypertensive disorders of pregnancy were the most common leading risk factors. Baseline haemoglobin and serum ferritin in both groups were clinically insignificant.[17][18]

\section{CONCLUSION}

The present study focused on prevalence of anaemia in postpartum women and its effective management with rapid and safe modes of treatment. The present study shows that supplementing with intravenous iron sucrose have a positive response on postpartum haemoglobin level. In the iron supplemented group, the haemoglobin level tends to increase from the baseline levels. Intravenous iron therapy administration increases the haemoglobin level more rapidly than oral iron intake of in women with iron deficiency anaemia in the postnatal period. Intravenous iron therapy also replenishes iron stores more rapidly than oral iron. It can be used as safe and effective alternative to blood transfusion and oral iron therapy in the treatment of iron deficiency anaemia in the postpartum period. Compliance can be ensured with the injectable iron group; however, the cost of injectable iron is more compared to iron tablets. If cost is not a limiting factor, limited dosage schedule of iron sucrose as prescribed in the study is a safe and effective alternative to daily oral iron taken in treatment of postpartum anaemia. Multiple child birth, poor socioeconomic status, dietary habits, type of habitat and education status of mother also contributed to the incidence of postpartum anaemia. Peripartum anaemia and complications during child birth also played an important role in the occurrence of postpartum anaemia. Present study found that postpartum anaemia had affected the practice of breastfeeding. This also affects the mother and child bonding. Future perspectives should include increased awareness to prevent and diagnose postpartum anaemia including screening of women at risk. Assessment of iron status (haemoglobin, ferritin) prior to delivery will help to define women at risk for postpartum iron deficiency and anaemia. Measurement of haemoglobin 24 - 48 hours after delivery will delineate women with anaemia who are in need of treatment with iron.

It may not be possible to set up the blood bank in every remote corner of the country, but it is certainly possible to make a blood bank in the woman's body by building up her haemoglobin.

\section{REFERENCES}

[1] http;//www.interscience.wiley.com/Cochrane.

[2] Milman N. Postpartum anemia I: definition, prevalence, causes, and consequences. Ann Hematol 2011;90(11):1247-53.

[3] Breymann C, Honegger C, Holzgreve W, et al. Diagnosis and treatment of iron-deficiency anaemia during 
pregnancy and postpartum. Arch Gynecol Obstet 2010;282(5):577-80.

[4] Danielson BG. Structure, chemistry and pharmacokinetics of intravenous iron agents. J Am Soc Nephrol 2004;15(Suppl 2):S93-8.

[5] Zhao A, Zhang Y, Li B, et al. Prevalence of anemia and its risk factors among lactating mothers in Myanmar. Am J Trop Med Hyg 2014;90(5):963-7.

[6] Bodnar LM, Scanlon KS, Freedman DS, et al. High prevalence of postpartum anemia among low-income women in the United States. Am J Obstet Gynecol 2001;185(2):438-43.

[7] Ali J, Das BP, Terangpi R. Effectiveness and safety of intravenous iron sucrose therapy in moderately anaemic pregnant women in third trimester. International Journal of Science and Research (IJSR) 2016;5(11):38-40.

[8] Somdatta P, Reddaiah VP, Singh B. Prevalence of anaemia in the postpartum period: a study of a North Indian village. Trop Doct 2009;39(4):211-5.

[9] Goodburn EA, Gazi R, Chowdhury M. Beliefs and practices regarding delivery and postpartum maternal morbidity in rural Bangladesh. Stud Fam Plann 1995;26(1):22-32.

[10] Kharde PS, Bangal VB, Panicker KK. Comparative study on intravenous iron sucrose and oral iron therapy in iron deficiency anaemia during postpartum period. Internatinal journal of biomedical and advance reaseac (IJBAR) 2012;3(4):238-24.
[11] Giannoulis C, Daniilidis A, Tantanasis T, et al. Intravenous administration of iron sucrose for treating anemia in postpartum women. Hippokratia 2009;13(1):38-40.

[12] Momen AK, al-Meshari A, al-Nuaim L, et al. Intravenous iron sucrose complex in the treatment of iron deficiency anemia during pregnancy. Eur J Obstet Gynecol Reprod Biol 1996;69(2):121-4.

[13] Hallak M, Sharon AS, Diukman R, et al. Supplementing iron intravenously in pregnancy. A way to avoid blood transfusions. J Reprod Med 1997;42(2):99-103.

[14] Bayoumeu F, Subiran-Buisset C, Baka NE, et al. Iron therapy in iron deficiency anemia in pregnancy: intravenous route versus oral route. Am J Obstet Gynecol 2002;186(3):518-22.

[15] Charytan C, Qunibi W, Bailie GR. Comparison of intravenous iron sucrose to oral iron in the treatment of anemic patients with chronic kidney disease not on dialysis. Nephron Clin Pract 2005;100:c55-c62.

[16] Kiran KV, Guru PB, Srinivasa RK, et al. Study of effect of intravenous iron sucrose in the treatment of puerperal anemia. Indian Journal of Pharmacy Practice 2010;3(4):14-7.

[17] Verma S, Inamdar SA, Malhotra N. Intravenous iron therapy versus oral iron in postpartum patients in rural area. Journal of SAFOG 2011;3(2):67-70.

[18] Rohina AS, Vineet MV, Navin PA, et al. Comparison of oral iron and IV iron sucrose for treatment of anemia in postpartum Indian women. National Journal of Community Medicine 2012;3(1):48-53. 